\title{
Terror-Crime Nexus? Terrorism and Arms, Drug, and Human Trafficking in Georgia
}

\author{
Colleen M. Traughber *
}

\section{Introduction}

Since the end of the Cold War and the subsequent proliferation of failed or failing states, particularly in Eastern Europe and Central Asia, transnational actors have increasingly taken advantage of gaps in law enforcement and security. Operating across borders (or transnationally), actors with illicit intentions - such as terrorist groups and organized criminal syndicates - effectively set the stage for the local, regional, and international problems that all states face today. As terrorists and criminals have gained stature, reports of collusion between these operationally separate groups in "gray areas" of the world have only increased, particularly in weak states. Accordingly, Georgia has not escaped unscathed from this new form of terror-crime collaboration. While links between terrorism and arms, drug, and even human trafficking are suspected, the existence of a nexus between terrorism and trafficking in Georgia is unclear and worthy of study. ${ }^{1}$

In many parts of the world - including Georgia - arms, drug, and human trafficking are linked to terrorism. ${ }^{2}$ Potentially, terrorists could use trafficking routes to transport operatives and trafficking profits used to finance their activities. While terrorists often depend on drug trafficking for income, their reliance on profits from human trafficking does not appear to be as substantial. ${ }^{3}$ In places where human trafficking represents a significant portion of organized criminal activity, such as parts of the former Soviet Union, a link with terrorism is suspected. ${ }^{4}$ In Georgia, terrorism and all varieties of

* Colleen Traughber is a Graduate Research Assistant at the Jebsen Center for Counter-Terrorism Studies at the Fletcher School of Law and Diplomacy, Tufts University. The author would like to thank the Jebsen Center for financial, intellectual, and moral support in completing this project. Specifically, Brigadier General (Ret.) Russell D. Howard played a major role in supporting the research that went into this project. The author would also like to acknowledge the Transnational Crime and Corruption Center-Caucasus Office (TraCCC-CO), which facilitated the research during the summer of 2006. Finally, the author would like to thank the Political/Economic Section of the U.S. Embassy in Tbilisi, Georgia for providing a bird's-eye view of the government of Georgia.

1 See, for example, Glenn E. Curtis, Involvement of Russian Organized Crime Syndicates, Criminal Elements in the Russian Military, and Regional Terrorist Groups in Narcotics Trafficking in Central Asia, the Caucasus, and Chechnya (Washington, D.C.: Federal Research Division, Library of Congress, 2002).

2 Louise Shelley, "Statement to the House Committee on International Relations, Subcommittee on International Terrorism, Nonproliferation and Human Rights," 25 June 2003; available at www.american.edu/traccc/resources/publications/shelle18.pdf.

3 Ibid.

4 Ibid. 
trafficking have only grown since Georgia gained independence, making the country (and region) critical to international security. ${ }^{5}$ The potential for collusion between terrorist and criminal groups only adds to an already unstable situation.

This study will examine the presence of a terror-crime "nexus" in Georgia, specifically focusing on potential points of intersection between terrorism and arms, drug, and human trafficking. First, this essay will outline the threat that transnational terrorism and international organized crime pose to Georgia. Next, through analysis based on the Preparation of the Investigative Environment (PIE) methodology, this paper will attempt to determine how and why terrorist and trafficking groups cooperate in Georgia. Finally, based on the results of the PIE analysis, this study will briefly assess current counterterrorism and counter-trafficking efforts in Georgia, and will offer a number of policy recommendations to counter both phenomena in the future.

\section{Background}

\section{Post-Cold War Problems: Transnational Terrorism and Organized Crime}

Since the end of the Cold War, political, economic, and social changes within the countries of the former Soviet Union have instigated a new set of problems, including illegal migration, terrorism, organized crime, and corruption, to name only a few. ${ }^{6}$ Both terrorist and criminal groups have taken advantage of the lack of law enforcement and regional security within the former Soviet Union, effectively transforming into transnational actors with nefarious intentions. As transnational actors, terrorists and criminals cross borders and openly transgress national laws, effectively operating outside of the reach of the state.

In the Caucasus, transnational terrorism has acquired an Islamist emphasis, as religious extremism has filtered in from the Middle East. Transnational terrorism in the Caucasus has been promoted by regional conflicts. Specifically, the war in Chechnya has evolved from a localized, ethnic conflict (the First Chechen War, 1994-96) to a focal point for foreign fighters who emphasize Islamic extremism (the Second Chechen War, 1999-present). Foreign fighters associated with the conflicts in separatist regions have carried out terrorist incidents in Russia, Georgia, and elsewhere. ${ }^{7}$ The Pankisi Gorge, a haven for foreign fighters in the past, now principally serves as one of many transit channels on the northern Georgian-Russian border. ${ }^{8}$

Since the collapse of the Soviet Union, arms, drug, and human trafficking have also developed into highly lucrative criminal activities within the former Soviet republics,

5 Kenneth Yalowitz and Svante E. Cornell, "The Critical but Perilous Caucasus," Orbis 48:1 (2004): 105-16.

6 Georgi Glonti, "Trafficking in Human Beings in Georgia and the CIS," Demokratizatsiya 9:3 (2001): 382-98.

7 Yalowitz and Cornell, "The Critical but Perilous Caucasus," 107.

8 Kakha Khizanishvili, Director, Police Academy, Georgian Ministry of Internal Affairs, Personal Communication, 13 July 2006. 
including Georgia. ${ }^{9}$ The trafficking of arms both to and from Georgia has risen since the end of the Cold War, and serves to fuel regional conflicts in Abkhazia, South Ossetia, and Chechnya. ${ }^{10}$ Drug trafficking is perhaps the most profitable of these criminal enterprises, with a reported USD 1 billion worth of drugs flowing through Georgia annually. ${ }^{11}$ In contrast to arms and drug trafficking, the covert nature of human trafficking makes it difficult to estimate the number of people trafficked each year. In the Caucasus, the number of human trafficking cases for sexual exploitation alone is estimated to be from 10,000 to 15,000 people annually. ${ }^{12}$ Unfortunately, there are no reliable statistics for the number of cases involving human smuggling. Although analysts and investigators disagree on the total number of people smuggled and trafficked per year, they concur that the problem is both significant and growing.

\section{Question and Hypothesis}

While a link or "nexus" between terrorism and arms, drug, and human trafficking is suspected, the nature of the nexus is at best ambiguous in Georgia. In general, Georgia remains at risk for both terrorism and trafficking. In order to determine if a nexus exists between terrorism and human trafficking in Georgia, this study asked the following questions:

- Are terrorists using the same routes as arms, drug, and human traffickers?

- Are terrorists using arms, drug, and human trafficking to finance their activities?

- Given the existence of a terror-crime "nexus," what are effective ways of countering terrorism and arms, drug, and human trafficking?

Based on indications from past studies, which suggest that a terror-crime nexus has emerged in Georgia, this study suggests the following hypotheses: ${ }^{13}$

- Terrorists are using the same routes as arms, drug, and human traffickers

- Terrorists are using arms, drug, and human trafficking to finance their activities

- Given the existence of a terror-crime "nexus," it may be easier to counter terrorism by penetrating groups that traffic in arms, drug, and humans.

The first two questions will be answered based on the use of Preparation of the Investigative Environment (PIE), an innovative methodology that looks at links between

9 Glonti, "Trafficking in Human Beings in Georgia and the CIS."

10 Alexandre Kukhianidze, Alexandre Kupatadze, and Roman Gotsiridze, Smuggling Through Abkhazia and Tskhinvali Region of Georgia (Tbilisi, Georgia: American University's Transnational Crime and Corruption Center [TraCCC], 2004), 32-34.

11 Moscow Interfax report from Tbilisi, 22 April 2002 (FBIS Document CEP2002042000161), as quoted in: LaVerle Berry, et al., Nations Hospitable to Organized Crime and Terrorism (Washington, D.C.: Federal Research Division, Library of Congress, 2003), 58.

12 Glonti, "Trafficking in Human Beings in Georgia and the CIS," 382.

13 For a comprehensive example, see Louise I. Shelley, et al., Methods and Motives: Exploring Links between Transnational Organized Crime and International Terrorism (Rockville, MD: National Criminal Justice Reference Service [NCJRS], 2005), 64-68. 
terrorism and crime that are appropriate for analysis and investigation. The third question will be answered based on qualitative policy analysis of current Georgian counterterrorism and counter-trafficking initiatives.

\section{Methodology: Preparation of the Investigative Environment (PIE)}

The analysis of potential terror-crime interaction in this study is based on a methodology known as Preparation of the Investigative Environment (PIE), which was derived from Intelligence Preparation of the Battlespace (IPB). Following IPB, analysts and investigators determine what is known and unknown about an adversary in order to determine the adversary's next move. ${ }^{14}$ Like IPB, PIE allows analysts and investigators to approach terrorist and criminal groups both tactically and strategically. Using PIE, analysts and investigators identify areas of potential terror-crime collaboration and interaction, thereby generating intelligence on potential future terrorist activity. ${ }^{15}$

The PIE method of analysis is a three-step process, which culminates in the identification of watch points and indicators. First, analysts and investigators map the areas where terrorist and crime groups are operating, develop typologies of the behavior patterns of the groups, and detail the organization of specific crime and terror groups. ${ }^{16}$ Second, they then identify "watch points," or broad categories of potential terror-crime interaction. ${ }^{17}$ Third, and finally, they collect and analyze information that indicates interaction between terrorist and criminal activity. ${ }^{18}$ These indicators of terror-crime collusion form the watch points. If indicators are clear and present, this points to the existence of terror-crime interaction.

The PIE methodology relies on a continuum of interaction between terrorist and criminal groups. Terms such as "nexus" or "hybrid," commonly used to describe terror-crime interaction throughout academic literature, remain too imprecise for a study of this nature. Thus, PIE analysts have created a terror-crime interaction spectrum, which details stages in the relationship between terrorist and criminal activities, including activity appropriation, nexus, symbiotic relationship, hybrid, and transformation. ${ }^{19}$ Activity appropriation is a relationship in which terrorist and criminal groups adopt similar methods without working together. Terrorist and criminal groups form a nexus when they begin to rely on the support and expertise of the other group. A more cooperative relationship, one of mutual benefit or dependence, is referred to as a symbiotic relationship. A relationship that involves the sharing of methods and motives is known as a hybrid. Finally, transformation occurs when terrorist groups abandon political motives entirely in order to pursue criminal objectives. Similarly, criminal groups can transform themselves completely from crime-based organizations into terrorist groups, although this is a rare occurrence.

\footnotetext{
14 Ibid., 22.

15 Ibid., 23.

16 Ibid., 28.

17 Idem.

18 Idem.

19 Ibid., 35-39.
} 


\section{Sources}

The research for this study came from a variety of sources, including academic literature; interviews with Georgian government officials, policy makers, and policy analysts; and official reports from both the U.S. government and international organizations. Much of the primary research was gathered during the summer of 2006, while I was based in Tbilisi, Georgia at the Transnational Crime and Corruption Center-Caucasus Office (TraCCC-CO). Because of the covert nature of the phenomena being studied, information on terrorism and arms, drug, and human trafficking was often difficult to access and incomplete. I made every effort to identify multiple sources for each incident of terrorism and human trafficking. The analysis in this study is mine and not attributable, unless otherwise noted, nor does it represent the point of view of any academic or governmental institution.

\section{Analysis}

\section{The Threat}

Georgia is primarily a transit state for both groups and activities associated with terrorism and organized crime. Located at the crossroads of Europe, the Middle East, and Central Asia, Georgia lies along a modern-day Silk Road-now a trading route for transnational terrorists and organized criminals, including arms, drug, and human traffickers. In addition to transit, Georgia is also, to a limited degree, an origin state for terrorists and, to a greater degree, an origin state for victims of human trafficking and all kinds of traffickers themselves. As analysts and investigators have noted (see below), the problems with terrorism and arms, drug, and human trafficking are only increasing in threat and scope.

Transnational terrorists, primarily those originating from the Middle East, are using Georgia as a transit location. Recently (2002-04), foreign fighters associated with the conflict in Chechnya used the Pankisi Gorge in Georgia as refuge. ${ }^{20}$ As a result, Georgia became a major transit state for foreign fighters with Islamic affiliations, who were transiting Georgia from the Middle East to Chechnya. ${ }^{21}$ According to the Office for the Coordinator for Counterterrorism at the U.S. Department of State, Georgia is also a transit country for arms, money, and supplies that are employed in planning terrorist attacks elsewhere and used by terrorists themselves. ${ }^{22}$

As the Council on Foreign Relations has reported, the foreign fighters transiting Georgia tend to be destined for the conflict in Chechnya, and often have proven links

20 Center for Defense Information (CDI), Terrorism Project, "Georgia: Fighting Terrorism in Another Failed State," 22 March 2002; available at www.cdi.org/terrorism/georgia.cfm.

21 U.S. Department of State, Office of the Coordinator for Counterterrorism, Country Reports on Terrorism, Chapter 5A - Country Reports (27 April 2005); available at www.state.gov/s/ $\mathrm{ct} / \mathrm{rls} / \mathrm{crt} / 45388 . \mathrm{htm}$.

22 U.S. Department of State, Office of the Coordinator for Counterterrorism, Country Reports on Terrorism, Chapter 5 - Country Reports: Europe and Eurasia Overview (28 April 2006); available at www.state.gov/s/ct/rls/crt/2005/64342.htm. 
to Al Qaeda. For example, the late Chechen warlord Ibn al-Khattab, a Jordanian by birth, was an associate of Osama bin Laden during the 1979-89 Soviet occupation of Afghanistan. ${ }^{23}$ In addition, Zacarias Moussaoui, the alleged "twentieth hijacker" in the 9/11 terrorist attacks, also operated as a recruiter for Al Qaeda-linked rebels in Chechnya. ${ }^{24}$ Furthermore, Chechen foreign fighters also reportedly joined forces with $\mathrm{Al}$ Qaeda and the Taliban in opposing the Northern Alliance (and ultimately the U.S.-led coalition force) in Afghanistan in $2001 .^{25}$

In addition to transnational terrorists, Georgia has a number of armed non-state actors that have been implicated in terrorist attacks, albeit predominately on a local level. These non-state groups include the Abkhaz military, the South Ossetian military, the White Legion, the Forest Brothers, the Hunter Battalion, and armed factions of ethnic Armenians. ${ }^{26}$ Primarily associated with the separatist conflicts in Georgia, these armed groups have caused a number of disturbances within Georgia proper in recent years. Additionally, the military of Nagorno-Karabakh operates in the region (but not in Georgia). In Armenia, regional groups include cells of the Kurdistan Workers' Party (PKK) and the Armenian Secret Army for the Liberation of Armenia (ASALA).

Georgia is a destination, transit, and origin state for illicit arms. The separatist regions of Abkhazia and South Ossetia are likely destinations for light arms; Georgian authorities have uncovered a number of cases involving the trafficking of machine guns, grenade launchers, grenades, pistols, and cartridges to these locations. ${ }^{27}$ Similar weapons also transit through Georgia, destined for the conflicts in the North Caucasus, particularly Chechnya. In addition, Georgia is an origin state for radiological and nuclear sources abandoned after the fall of the Soviet Union. ${ }^{28}$

Drug trafficking is an entrenched problem in Georgia because of its location on the transit route through the Caucasus. ${ }^{29}$ The criminal groups involved in narcotics trafficking in the region originate from Abkhazia, South Ossetia, Chechnya, and Azerbaijan, as well as from other former Soviet republics and Turkey. ${ }^{30}$ In the past, the Pankisi Gorge, a lawless region on the Georgian-Russian border, has also operated as a transit location to transfer drugs from Central Asia to Russia, effectively supporting the

23 Council on Foreign Relations, "Chechnya-based Terrorists (Russia, separatist)" (updated 11 July 2006); available at www.cfr.org/publication/9181/\#1.

24

25

26

26 These groups are best described as "non-state armed groups." They operate outside of the state and are more adequately described as guerilla groups rather than terrorist organizations. See Table: "Selected Non-State Armed Groups," The Military Balance 104:1 (2004): 36364.

27 Kukhianidze, Kupatadze, and Gotsiridze, Smuggling Through Abkhazia and Tskhinvali Region of Georgia, 33.

28 Alexandre Kukhianidze, Director, Transnational Crime and Corruption Center-Caucasus Office (TraCCC-CO), Personal Communication, 27 July 2006.

29

30

Berry, et al., Nations Hospitable to Organized Crime and Terrorism, 58.

Ibid., 58. 
conflict in Chechnya. ${ }^{31}$ Because drug trafficking is such a profitable business, it has persisted despite the best efforts of Georgian and Russian authorities.

According to the Office to Monitor and Combat Trafficking in Persons at the U.S. Department of State, Georgia is a "Tier II" country, which means that it does not fully comply with the Victims of Trafficking and Violence Protection Act's (VTVPA) minimum standards, but is making significant efforts to bring itself into compliance with those standards. ${ }^{32}$ Georgia is both a source and transit country for victims of human trafficking. Humans are trafficked through Georgia from places like Ukraine, Russia, and other former Soviet republics to various locations, including the United Arab Emirates (UAE), Turkey, Greece, Western Europe, and the United States. ${ }^{33}$

In the aftermath of multiple conflicts during the 1990s, the South Caucasus became a center for trafficking in women and illegal migration. ${ }^{34}$ The United Nations Office on Drugs and Crime (UNODC) has identified Georgia as having a "high" incidence of origin, ${ }^{35}$ a "medium" incidence of transit, ${ }^{36}$ and a "very low" incidence as a country of destination. ${ }^{37}$ The majority of victims are women and children, who are typically trafficked for sexual exploitation. However, there have been a number of incidents of the trafficking of men and older boys for forced labor. ${ }^{38}$

\section{The Indicators}

Open Activities in the Legitimate Economy. Terrorists - and, to a greater degree, criminals - can and do operate openly within the Georgian economy and society. For example, non-state armed groups in both Abkhazia and South Ossetia have either official or unofficial links to the de facto regimes and organizations in these separatist regions. Furthermore, Okan, a coal mining company in Abkhazia, has been implicated in the transit of workers from Turkey into Abkhazia. ${ }^{39}$ Activities associated with human trafficking are prevalent in the open economy.

Flagrant incidents of human trafficking are a significant problem in Trabzon, the Turkish Black Sea port, which is located on the border with Georgia. ${ }^{40}$ This is one of the main routes of human trafficking from Georgia. Here, notably, women are even

31 Ibid., 59.

32 U.S. Department of State, Trafficking in Persons Report (June 2005); available at www.state.gov/g/tip/rls/tiprpt/2005/46606.htm.

33 Ibid.

34 Yalowitz and Cornell, "The Critical but Perilous Caucasus," 105.

35 United Nations Office on Drugs and Crime (UNODC), Trafficking in Persons Report, "Trafficking in Persons: Global Patterns" (April 2006), 18.

36 Ibid., 19.

37 Ibid., 20.

38 United Nations Office on Drugs and Crime (UNODC), Trafficking in Persons Report, "Trafficking in Persons: Global Patterns," Appendices, 106.

39 Ministry of State Security of the Government of Abkhazia in Exile, 2003, cited in Kukhianidze, Kupatadze, and Gotsiridze, Smuggling Through Abkhazia and Tskhinvali Region of Georgia, 36.

40 Alexandre Kukhianidze, Personal Communication, 27 July 2006. 
trafficked by other women. These women are extremely poor, typically from rural villages, and are often illiterate, and thus are desperately in search of employment. ${ }^{41}$ They often use employment agencies, which are really fronts for human trafficking operations.

Shared Illicit Nodes. Both terrorists and criminals have established regular transnational routes of transit through Georgia and the South Caucasus. The Transnational Crime and Corruption Center-Caucasus Office ${ }^{42}$ and the Organization for Security and Cooperation in Europe (OSCE) Mission to Georgia ${ }^{43}$ have documented the routes of illegal activities through Georgia. Terrorists tend to travel through Georgia from the south (originating from the Middle East) and the east (beginning in Afghanistan). Since terrorist destinations are typically areas north of Georgia and in Russia, such as Chechnya and Dagestan, Georgia is used mainly as a transit country. As recently as early 2006, the Georgian Ministry of Internal Affairs uncovered a case in which a Saudi national attempted to transit Georgia, relying on the Chechen network in Tbilisi and throughout Georgia to aid his illicit migration. ${ }^{44}$

Drug Trafficking. Drugs travel from Afghanistan through Dagestan and Georgia, both of which are primarily transit zones (instead of destinations). ${ }^{45}$ Drug traffickers also transit through the Pankisi Gorge, South Ossetia, and Abkhazia in order to reach Russia, ${ }^{46}$ and drugs are trafficked to Georgia from Azerbaijan. ${ }^{47}$ A major exit point for drug traffickers is through Sarpi, Georgia to Turkey. ${ }^{48}$ Under Aslan Abashidze, the former de facto leader of the self-proclaimed "Autonomous Republic of Adjara," Batumi was a major transit port for drugs. ${ }^{49}$ Abashidze was also involved in trafficking drugs from Turkey to Russia. ${ }^{50}$ Drug trafficking remains a problem in this region; in 2004, a large quantity of heroin was found on the Georgian-Turkish border in a double-bottomed truck. $^{51}$

41 Ibid.

42 Kukhianidze, Kupatadze, and Gotsiridze, Smuggling Through Abkhazia and Tskhinvali Region of Georgia, 11.

Bogdan Udriste, Advisor, OSCE Mission to Georgia, Personal Communication, 28 September 2006.

Giorgi Gabunia, Head of Counterterrorism Center, Ministry of Internal Affairs of Georgia, Personal Communication, 18 July 2006.

Kakha Khizanishvili, Director, Police Academy, Ministry of Internal Affairs, Personal Communication, 13 July 2006.

Georgi Glonti, Director, Department of External Affairs, Georgian University of Social Sciences, Personal Communication, 25 July 2006.

Sven Holdar, Deputy Head of Human Dimension Office, Organization of Security and Cooperation in Europe, Personal Communication, 7 July 2006.

Ibid.

49 Kakha Khizanishvili, Personal Communication, 13 July 2006.

50 Georgi Glonti, Personal Communication, 25 July 2006.

51 Ibid.

51 Giorgi Gabunia, Personal Communication, 18 July 2006. 
Outside of heroin and marijuana trafficking, Subutex smuggling accounts for 60 percent of the drug market in Georgia. ${ }^{52}$ A synthetic drug intended to be used to treat opium addiction, Subutex actually comes to Georgia from Western Europe, typically originating in France, Belgium, and the Netherlands. ${ }^{53}$ Criminals use second-hand cars to transport the drug. Subutex can generate a huge profit in Georgia: while it is sold for 1 Euro in Belgium, a dose sells for 100 Euros in Georgia. In one case, 1,000 tablets were found in a car, which would have generated USD 100,000 in profit. ${ }^{54}$ The smuggling of Subutex is a relatively new phenomenon, which has the potential to have a huge impact on Georgia if it is left unchecked.

Weapons. After the end of the Cold War, the Georgian Ministry of the Environment discovered more than 270 sources of radiological materials. ${ }^{55}$ These sources include research reactors and radiological waste, among other things. Additional radiological materials were abandoned in forests by Russian troops as they withdrew. The trafficking route for radiological or nuclear materials through Georgia flows from Central Asia through the Caucasus to the Middle East. ${ }^{56}$ A common route is from Russia through South Ossetia to Batumi or Armenia. There have been at least two cases in which traffickers of radiological materials attempted to sell materials in Batumi. In one case, the traffickers were detained on the Georgian-Armenian border; in the other, they were detained as they attempted to smuggle the materials out of Armenia. ${ }^{57}$

Human Trafficking. Victims of human trafficking typically come from two regions: the eastern South Caucasus (specifically, Armenia and Azerbaijan) or the former Soviet Union (particularly Belarus, Moldova, and Ukraine) ${ }^{58}$ They transit Georgia, ultimately destined for Turkey or the Middle East. ${ }^{59}$ The Ministry of State Security of the Government of Abkhazia in Exile has uncovered a number of cases of human smuggling from Turkey to Abkhazia. In one case, twelve people from Turkey were detained at the Rukhi Bridge on the border between Abkhazia and Georgia. ${ }^{60}$ In this case, the coal mining company Okan had allegedly offered them employment in Abkhazia for USD 700 to 1,000 per month. $^{61}$

The Georgian Coast Guard discovered another incident involving human smuggling from Turkey to Abkhazia. In this case, at least four people were smuggled to Abkhazia

52 Alexandre Kukhianidze, Director, Transnational Crime and Corruption Center-Caucasus Office (TraCCC-CO), Personal Communication, 27 July 2006. Ibid.

54 Ibid.

55 Ibid.

56 Ibid.

57 Ibid.

58 Georgi Glonti, Personal Communication, 25 July 2006.

59 Ibid.

${ }^{60}$ Ministry of State Security of the Government of Abkhazia in Exile, 2003, cited in Kukhianidze, Kupatadze, and Gotsiridze, Smuggling Through Abkhazia and Tskhinvali Region of Georgia, 36 .

${ }^{61}$ Ibid., 36. 
to work in a coal mine, ostensibly with high salaries. ${ }^{62}$ When the miners instead found themselves working under slave-like conditions, they attempted to escape by boat, and were intercepted by the Georgian Coast Guard. ${ }^{63}$ Furthermore, the Georgian Department of Intelligence has implicated Turkish ships in the trafficking of groups of five or six women from Russia to Abkhazia and on to Turkey. ${ }^{64}$

Use of Violence. Recent terrorist attacks in Georgia include a car bomb explosion outside of the police station in Gori, Georgia (5 February 2005) ${ }^{65}$ and an unsuccessful grenade attack against U.S. President George W. Bush in Tbilisi's Freedom Square (20 May 2005) ${ }^{66}$ In another incident, on 22 January 2006, high-voltage electricity lines were destroyed. ${ }^{67}$ In 1999, there was an explosion in Zugdidi (Abkhazia). ${ }^{68}$ In the Caucasus region, a Georgia-related terrorist attack occurred when Chechen terrorists took over a school in Beslan, Russia (located in North Ossetia), creating a hostage crisis. While the terrorists were mostly Chechens, the group included two people of Arab origin. ${ }^{69}$ The group reportedly came to Beslan from South Ossetia-a separatist region in Georgia - through the Roki Tunnel. ${ }^{70}$

In the past, news reports have indicated the practice of slavery or forcible servitude in Abkhazia. For example, Region Inform, the Russian information agency, reported that officials at a Russian border checkpoint apprehended a man who was trying to illegally cross into Russia. ${ }^{71}$ Originally from Murmansk, Oleg Kalinov claimed that he had been forced to work as a slave in Abkhazia since 1993. Moreover, reports of slavery were confirmed in the summer of 2006, after troops from the Georgian Ministry of Internal Affairs forcibly retook the Kodori Gorge, a region on the periphery of

${ }^{62}$ Department of the Border Guard of Georgia, 2003, cited in ibid., 36.

${ }^{63}$ Ibid, 36.

${ }^{64}$ Department of Intelligence of Georgia, 2003, cited in ibid., 36.

65 "World Briefing-Europe: Georgia: Car Bomb Kills 3 Policemen," New York Times (2 February 2005); available at http://query.nytimes.com/gst/fullpage.html?res=9D03E7DB133BF93 1A35751C0A9639C8B63.

${ }^{66}$ Elaine Quijano, "Secret Service Told Grenade Landed near Bush: U.S. Officials Investigating Alleged Incident in Georgia," CNN.com (10 May 2005); available at www.cnn.com/ 2005/WORLD/europe/05/10/bush.georgia/index.html.

${ }^{67}$ Kakha Khizanishvili, Director, Police Academy, Ministry of Internal Affairs, Personal Communication, 13 July 2006.

${ }^{68}$ Giorgi Gabunia, Head of Counterterrorism Center, Ministry of Internal Affairs of Georgia, Personal Communication, 18 July 2006.

69 Energy Security Analysis, Inc. (ESAI), Weekly Intelligence Briefing, "Russia's Counterterrorism Strategy after Beslan-Regional Implications," 30 September 2004; available at www.esai.com/pdf/Wb092004.pdf.

${ }^{70}$ Vladimir Socor, "JCC, 'Peacekeeping' Formats in South Ossetia Shown to be Untenable," Eurasia Daily Monitor 2:199 (26 October 2005); available at http://www.jamestown.org/ publications_details.php?volume_id=407\&issue_id=3506\&article_id $=2370394$.

${ }^{71}$ Cited in Kukhianidze, Kupatadze, and Gotsiridze, Smuggling Through Abkhazia and Tskhinvali Region of Georgia, 36. 
Abkhazia, and officials discovered the presence of Georgian slaves among the Abkhazian inhabitants. ${ }^{72}$

Use of Corruption. Particularly in the past, when the Pankisi Gorge was a problematic region, high-ranking Georgian state authorities were involved in illicit activities. ${ }^{73}$ The involvement tended to occur at the departmental chief level and higher. Specifically, in 2000, there were fighters of both Chechen and Arab origin in the Pankisi Gorge. ${ }^{74}$ Chechen field commanders apparently gave money to the Georgian government and tried to gain sympathy among the locals in order to be able to remain there. ${ }^{75}$ At the same time, there was evidence of drug trafficking in the Pankisi Gorge. ${ }^{76}$ This is an example of direct collusion between terrorist and criminal groups. Some terrorist threat still continues to emanate from the Pankisi Gorge; it will take time for the problem to be resolved. ${ }^{77}$ Now, however, South Ossetia has taken over as the country's main hub for drug trafficking, with both Georgia and Chechen criminal groups involved. $^{78}$

In the recent past, both criminal and terrorist groups have arguably had more opportunity for collusion in Georgia proper through the patronage of government officials. During the tenure of Aslan Abashidze, the Adjaran regime was notorious for its links to Chechen terrorist groups and Russian organized crime groups. Furthermore, in Georgia, law enforcement and border guards throughout the country were commonly known to be corrupt - even in the aftermath of the Rose Revolution ${ }^{79}$ —allowing for freedom of movement and action for terrorists and criminals alike. There is evidence to suggest that criminals continue to be protected by government officials because of corruption. ${ }^{80}$

Much of the former Georgian system encouraged corruption related to all kinds of trafficking. The old Georgian passport is extremely easy to forge; the photo can be changed, and the passport could be used multiple times. In one case, a passport was used at least fifteen different times by different people. ${ }^{81}$ It is relatively easy to buy

72 Zaza Jgharkava, "Possible Case of Slavery Discovered in Svaneti," Georgia Today, Issue 318 (10 August 2006); available from www.georgiatoday.ge/article_details.php?id=1615.

73 Georgi Glonti, Director, Department of External Affairs, Georgian University of Social Sciences, Personal Communication, 25 July 2006.

74 Giorgi Gabunia, Head of Counterterrorism Center, Ministry of Internal Affairs of Georgia, Personal Communication, 18 July 2006.

75 Ibid.

76 Marc Hulst, Counter-Trafficking Program Officer, International Organization for Migration, Personal Communication, 11 July 2006.

77 Ibid.

78 Kakha Khizanishvili, Director, Police Academy, Ministry of Internal Affairs, Personal Communication, 13 July 2006.

79 Ibid.

80 Sven Holdar, Deputy Head of Human Dimension Office, Organization for Security and Cooperation in Europe, Personal Communication, 7 July 2006.

81 Georgi Glonti, Director, Department of External Affairs, Georgian University of Social Sciences, Personal Communication, 25 July 2006. 
falsified documents in Georgia; for as little as USD 400, traffickers can obtain such documents. ${ }^{82}$ The laxity of the Georgian travel document regime only encourages further trafficking activities. As recently as 2001, firms and agencies within Georgia facilitated visa brokerage. ${ }^{83}$ These firms also assisted in the smuggling of people, but not trafficking for prostitution purposes.

Financial Transactions and Money Laundering. Chechen terrorist groups maintain known financial links to global Wahhabi extremists. ${ }^{84}$ These foreign fighters transit Georgia in order to reach Chechen freedom fighters based in the Pankisi Gorge. Chechen-led groups have used the Pankisi Gorge, within the territory of Georgia, for training camps, taking advantage of the lawlessness there. Chechens use the mountainous northern border to transport supplies, information, and particularly money. ${ }^{85}$ Some of this money is carried across the northern border by foreign fighters to support the conflict in Chechnya.

There have been a number of kidnappings in which victims, mostly foreigners of some financial means, were taken or trafficked to the Pankisi Gorge region. ${ }^{86}$ The victims were often involved in the banking business, and thus were relatively wealthy individuals. In these instances, the traffickers benefited directly from the lawlessness in the Pankisi Gorge, just as do the terrorist groups that operate there, far from the reach of state power. The kidnappings were not organized by the Chechens, but by criminal groups that negotiated with the Chechens. ${ }^{87}$ Now, the Georgian government has (for the most part) regained control of the Pankisi Gorge. The separatist regions, however, remain uncontrolled, and incidents of kidnappings have been prevalent there. ${ }^{88}$

Organizational Structures. Since Georgia gained independence, over one million people have left the country. ${ }^{89}$ Many have fled by using smuggling networks, which charge anywhere from USD 5,000 to 10,000 for safe passage to the West. (Given the significant amount charged by the traffickers, many Georgians cannot afford to pay the full amount up front. In some cases the victim remains indebted to the trafficker until the debt can be repaid. $)^{90}$ In 2004, thirteen women from Uzbekistan were found in an apartment in Tbilisi en route to Dubai; the traffickers included both Armenians and

82 Sven Holdar, Personal Communication, 7 July 2006.

83 Marc Hulst, Counter-Trafficking Program Officer, International Organization for Migration, Personal Communication, 11 July 2006.

85

Kakha Khizanishvili, Director, Police Academy, Ministry of Internal Affairs, Personal Communication, 13 July 2006.

85 Giorgi Gabunia, Head of Counterterrorism Center, Ministry of Internal Affairs of Georgia, Personal Communication, 18 July 2006.

86

87

88

Sven Holdar, Deputy Head of Human Dimension Office, Organization for Security and Cooperation in Europe, Personal Communication, 7 July 2006.

90 
Georgians. ${ }^{91}$ This is an example of the more decentralized, loosely knit network that is typical of transnational organized crime. Although there are not many examples of such an organizational structure within Georgia, where human trafficking tends to happen on an ad hoc basis, similar networks may be at play in both arms and drug trafficking.

Culture. The Chechens and Kists in Georgia share common cultural roots and speak the same language. Prior to Georgian military operations in the Pankisi Gorge, terrorists and foreign fighters from Chechnya were based there. Today, mainly Chechen refugees remain, although foreign fighters freely transit the region. ${ }^{92}$ In addition, terrorist groups in Chechnya have used Chechen women (ages 17 to 20) as suicide bombers. ${ }^{93}$ Chechens have also been involved in the illegal smuggling of human beings to the region. In this case, terrorism is directly connected to human trafficking.

In addition to the Kists in the Pankisi Gorge, ethnic and religious minorities throughout Georgia assist in the transit of individuals through the country. For example, over 300,000 Muslims live in Georgia. There is a large Muslim community close to Tbilisi that functions as potential support group for traffickers. Chechens of Muslim origin within Tbilisi proper have in the past sheltered and continue to harbor foreign fighters as they transit the country, destined for Chechnya. ${ }^{94}$ In total, only 2.5 million ethnic Georgians live in Georgia, out of a total population of 4.6 million.

Popular Support. According to the Georgian Ministry of Internal Affairs, the separatist region of South Ossetia has had links to terrorists and terrorist activity. Allegedly, South Ossetia contained training camps for foreign fighters. ${ }^{95}$ In addition, chemical weapons, radiological weapons, and nuclear devices were transported through South Ossetia intended for use by terrorist or criminal groups. The transport was supported by the official South Ossetian armed militias, which defend the separatist region.

As separatist enclaves, South Ossetia and Abkhazia are logical transit zones in Georgia because of absence of law enforcement by the central government. Reportedly, unregulated people are entering South Ossetia through the Roki Tunnel. ${ }^{96}$ From South Ossetia, these people easily transit through to Georgia. Abkhazia is also a transit zone, but is less conducive to the passage of migrants. While the Sochi border separating Russia and Abkhazia is uncontrolled, it is not as easy to cross the Abkhazian borders due to the terrain. ${ }^{97}$

91 Ibid.

92 Khatuna Madurashvili, Program Director, Refugee Council of Georgia, United Nations Association, Personal Communication, 18 July 2006.

93 Alexandre Kukhianidze, Director, Transnational Crime and Corruption Center-Caucasus Office (TraCCC-CO), 27 July 2006.

94 Giorgi Gabunia, Head of Counterterrorism Center, Ministry of Internal Affairs of Georgia, Personal Communication, 18 July 2006. Ibid.

96 Marc Hulst, Counter-Trafficking Program Officer, International Organization for Migration, Personal Communication, 11 July 2006. Ibid. 


\section{Terror-Crime Nexus?}

Applying the PIE methodology has revealed a number of points about the collusion of terrorist and criminal elements in Georgia, and thus is able to apply these points to the hypotheses put forth at the beginning of this paper. First, both terrorists and human traffickers in Georgia are benefiting from a general lack of law enforcement and loose border control - problems that are endemic to Georgia and its neighbors in the Caucasus. As a result, both terrorists and criminals use similar, if not the same, passages of transport. As such, the first conclusion of this study is: Terrorists are using the same routes as arms, drug, and human traffickers. In the sense that terrorists and human traffickers are benefiting from the same environment, terrorists and human traffickers are "linked."

This study has shown that "narcoterrorism" and arms-supported terrorism is present in Georgia. Notably, this study has revealed that direct collusion between terrorists and human traffickers, although implied in the limited literature as noted previously, is not evident within Georgia. Thus, the second conclusion of this study is: Terrorists are using arms and drugs trafficking - but not human trafficking-to finance their activities. Thus, terrorists and drug traffickers have formed a "nexus" or even, in some cases, a "hybrid" organization, while terrorists and arms traffickers have formed a "symbiotic relationship." In contrast, terrorists and human traffickers in Georgia most adequately resemble "activity appropriation" along the continuum of terror-crime interaction, and have not yet progressed to the status of "nexus." Indicators of collusion between terrorists and human traffickers are generally less apparent across Georgia.

The previous two conclusions have direct implications for counterterrorism and counter-trafficking policy in Georgia. Accordingly, the third conclusion is: Because of the "nexus" and "symbiotic relationship" between terrorism and drug and arms trafficking (respectively), terrorism can be countered by penetrating drug and arms traffickers. However, since a terror-crime "nexus" does not exist between terrorism and human trafficking, terrorism and human trafficking should be countered separately. Unlike countering "narcoterrorism" and arms-financed terrorism-both of which are possible to combat by infiltrating traffickers in order to more effectively counter affiliated terrorist groups - there is little to no value in countering terrorism by infiltrating groups involved in human trafficking.

\section{Policy Analysis and Recommendations}

\section{Policy Analysis}

Although Georgia has taken steps to counter terrorism and arms, drug, and human trafficking, the country (and the South Caucasus in general) continues to have a problem with both phenomena. While these phenomena are not always directly linked, they do benefit from the same atmosphere of lawlessness and the lack of a secure environment. Georgia has arguably employed separate policies to counter terrorism and trafficking, yet the government of Georgia has been relatively unsuccessful in countering both 
phenomena simultaneously. The individual policies have been ineffective to varying degrees.

In 2005, the Counterterrorism Center was created within the Georgian Ministry of Internal Affairs. With this new center, the ministry effectively has augmented its ability to gather and analyze data. The center is dependent upon the cooperation of the Special Services, foreign intelligence, border guards, financial monitoring services, and allies. Border security, an enduring problem in Georgia, has particularly improved in the recent past as a result of increased cooperation among multiple departments, driven by the Counterterrorism Center. In fact, within the last year, ten people were detained on the Georgian border because they did not have the proper documents. ${ }^{98}$

In 2005, over ninety Georgian officials participated in Antiterrorism Assistance (ATA) programs sponsored by the U.S. Department of State. ${ }^{99}$ In addition, Georgian troops have participated in the U.S. Department of Defense-sponsored Georgian Train and Equip Program (GTEP) and Georgian Sustainment and Stability Operations Program (GSSOP), which are intended to enhance Georgia's counterterrorism capabilities and help it address the security challenge posed by the Pankisi Gorge. Despite the best work of GTEP and GSSOP, the Pankisi Gorge (and the northern border in general) still remains a transit location for foreign fighters bound for Chechnya. As a result, Georgian troops continue to work to rid the Pankisi Gorge of terrorists. ${ }^{100}$ The Gorge remains a location of arms and drug trafficking, as well as a transit zone for money and supplies.

The problems with arms, drug, and particularly human trafficking have gained recognition within Georgia in recent years. To combat human trafficking, the Georgian government has focused on prosecution, protection, and prevention. ${ }^{101}$ In contrast, Georgia has been unable to mitigate the growth of drug trafficking, particularly in the Pankisi Gorge, a region that involves international players. Like drug trafficking, arms trafficking remains a transnational problem, requiring a like response.

\section{Policy Recommendations}

The Georgian government should recognize that terrorism and arms, drug, and human trafficking are linked to varying degrees, but that they flourish under the same conditions - namely, an absence of central state control. While terrorists and drug and arms traffickers tend to work hand-in-hand, terrorists and human traffickers both benefit from porous borders and a lack of law enforcement. While terrorist and trafficking groups are not colluding to form a "nexus," they do appropriate similar activities.

98 Giorgi Gabunia, Head of Counterterrorism Center, Ministry of Internal Affairs of Georgia, Personal Communication, 18 July 2006.

99 U.S. Department of State, Office of the Coordinator of Counterterrorism, Country Reports on Terrorism (April 2006), 100; available at www.state.gov/documents/organization/65462.pdf. 100 Ibid.

${ }^{101}$ U.S. Department of State, Trafficking in Persons Report (June 2005); available at www.state.gov/g/tip/rls/tiprpt/2005/46606.htm. 
Counterterrorism Policy Recommendations. The following recommendations are intended to provide a framework for Georgia's response to the presence of terrorist groups operating in or transiting though Georgian territory:

- It is necessary for Georgia to deepen and enhance the coordination of regional and international counter-terrorism efforts. Transnational terrorism does not have borders. Greater integration of Georgia within international organizations such as NATO is crucial.

- The Georgian Ministry of Internal Affairs should continue to utilize the counterterrorism department, while focusing on greater inter-agency coordination.

- Georgian troops should continue to train and modernize. Georgia should be prepared to support stability operations in case regional conflicts should expand into Georgian territory.

- Georgian border guards need to work more closely with officials from their neighboring states: Armenia, Azerbaijan, Russia, and Turkey.

Counter-Trafficking Policy Recommendations. The following recommendations are focused on ways that Georgia can address the presence of arms, drugs, and human trafficking networks within Georgian territory and the region more broadly:

- Law enforcement officials in Georgia need to work with their counterparts in neighboring states that also host trafficking routes, particularly Turkey. They also should work closely with international partners.

- The Georgian Ministry of Internal Affairs should create a special department (modeled after the counterterrorism department) so that inter-agency action within the law enforcement community is possible.

- Georgian law enforcement officials should recognize the collusion between terrorists and traffickers and use this information to infiltrate appropriate groups, particularly arms and drug traffickers.

- Georgia needs to pursue and enact bilateral policies with neighboring countries. As they are transnational issues, arms, drug, and human trafficking can only be countered with transnational action.

\section{Conclusion}

This study illuminated the links (or lack thereof) between terrorism and trafficking in Georgia. It revealed that terrorism is linked to the trafficking of arms - and particularly of drugs - in this country. While this study did not find evidence of links between terrorist organizations and human trafficking groups in Georgia, it did point to common indicators of terrorism and human trafficking within Georgia. By creating a more secure environment and more thoroughly instituting the rule of law, the Georgian government could make great strides in countering both terrorism and trafficking across the board. 
Since the Rose Revolution in November 2003, a new, proactive regime has come into power in Tbilisi. The stagnation of the previous decade appears to be a thing of the past; President Mikheil Saakashvili is willing and able to implement new policies, which aim to change much of the status quo within Georgia. Change, however, does not happen overnight. Terrorism, crime, and corruption still persist in Georgia, even in the aftermath of the Rose Revolution. As the new regime introduces new policies, it must aim for long-term solutions. 


\section{THE QUARTERLY JOURNAL}

\section{Bibliography}

Chechnya-based Terrorists (Russia, separatist). Council on Foreign Relations, 2006.

Country Reports on Terrorism - Chapter 5A. U.S. Department of State, Office of the Coordinator for Counterterrorism, 2005.

Country Reports on Terrorism, Chapter 5 - Country Reports: Europe and Eurasia Overview. U.S. Department of State, Office of the Coordinator for Counterterrorism, 2006.

Curtis, Glenn E.. Involvement of Russian Organized Crime Syndicates, Criminal Elements in the Russian Military, and Regional Terrorist Groups in Narcotics Trafficking in Central Asia, the Caucasus, and Chechnya. Washington, D.C.: Federal Research Division, Library of Congress, 2002.

Georgia: Fighting Terrorism in Another Failed State. Center for Defense Information (CDI), 2002.

Glonti, Georgi. "Trafficking in Human Beings in Georgia and the CIS." Demokratizatsiya 9, no. 3 (2001): 382-98.

Jgharkava, Zaza. "Possible Case of Slavery Discovered in Svaneti." Georgia Today 318 (2006).

Kukhianidze, Alexandre, Alexandre Kupatadze, and Roman Gotsiridze. Smuggling Through Abkhazia and Tskhinvali Region of Georgia. Tbilisi, Georgia: American University's Transnational Crime and Corruption Center [TraCCC], 24.

Nations Hospitable to Organized Crime and Terrorism - Moscow Interfax report from Tbilisi. Washington, D.C.: Federal Research Division, Library of Congress, 2003.

Quijano, Elaine. Secret Service Told Grenade Landed near Bush: U.S. Officials Investigating Alleged Incident in Georgia. CNN.com, 2005.

Russia's Counterterrorism Strategy after Beslan-Regional Implications In Weekly Intelligence Briefing. Energy Security Analysis, Inc. (ESAI), 2004.

Selected Non-State Armed Groups. The Military Balance 104, no. 1 (2004): 363-64.

Shelley, Louise I.. Methods and Motives: Exploring Links between Transnational Organized Crime and International Terrorism. Rockville, MD: National Criminal Justice Reference Service [NCJRS], 2005.

Shelley, Louise. Statement to the House Committee on International Relations, Subcommittee on International Terrorism, Nonproliferation and Human Rights., 2003.

Socor, Vladimir. "Peacekeeping' Formats in South Ossetia Shown to be Untenable." Eurasia Daily Monitor 2, no. 199 (2005). 
Trafficking in Persons Report "Trafficking in Persons: Global Patterns". United Nations Office on Drugs and Crime (UNODC), 2006.

Trafficking in Persons Report . U.S. Department of State, 2005.

World Briefing-Europe: Georgia: Car Bomb Kills 3 Policemen. New York Times (2005).

Yalowitz, Kenneth, and Svante E. Cornell. "The Critical but Perilous Caucasus." Orbis48, no. 1 (2004): 105-16. 